\title{
PENGARUH BRAND IMAGE DAN HARGA TERHADAP KEPUTUSAN PEMEBELIAN DETERJEN MEREK RINSO DI DESA PAGAR KAYA KECAMATAN SUNGAI KERUH
}

\author{
Sri Gustini ${ }^{1}$ \\ ${ }^{1}$ srigustini.mudrik@gmail.com \\ STIE Rahmaniyah Sekayu, Sumatera Selatan, Indonesia
}

\begin{abstract}
Abstrak.Brand image dan harga merupakan syarat yang sangat kuat dalam pengambilan keputusan pembelian. Penguatan brand image dan harga dimata konsumen ini juga digunakan oleh perusahaan-perusahaan untuk memperkuat posisinya dalam peta persaingan deterjen yang ada di Indonesia. pada penelitian ini, variabel yang digunakan adalah brand image $\left(\mathrm{X}_{1}\right)$, harga $\left(\mathrm{X}_{2}\right)$. Kedua variabel tersebut diuji pengaruhnya terhadap Keputusan Pembelian (Y) baik secra parsial maupun simultan. Sampel yang digunakan adalah konsumen deterjen Rinso di Desa Pagar Kaya Kecamatan Sungai Keruh yang berjumlah 110 orang, yang dipilih menggunakan rumus Maholtra. Metode analisis data menggunakan Analisis Regresi Berganda. Hasil analisis menunjukkan bahwa variabel brand image $\left(\mathrm{X}_{1}\right)$ berpengaruh secara signifikan terhadap Keputusan Pembelian (Y). hal ini muncul karena brand image yang positif terbentuk dibenak konsumen. Variabel harga $\left(\mathrm{X}_{2}\right)$ juga berpengaruh terhadap Keputusan Pembelian (Y). hal ini karena harga juga menjadi pertimbangan konsumen dalam melakukan pembelian. Besarnya pengaruh brand image dan harga terhadap keputusan pembelian dipengaruhi oleh citra dan harga yang sudah terbentuk dibenak konsumen.
\end{abstract}

Kata Kunci : Brand Image, Harga, Keputusan pembelian.

\section{Pendahuluan}

Persaingan dunia usaha yang berkembang dimasa ini yang telah melahirkan kondisi ketat dalam persaingan disegala macam bidang, termasuk didalam persaingan bisnis yang semakin menuntut perusahaan harus mengikuti dengan teliti. Perubahan prilaku konsumen didalam mengambil sebuah keputusan baik dalam membeli, mengkonsumsi, ataupun menggunakan suatu produk. Dengan dilihat dari kondisi tersebut, menyebabkan perusahaan semakin dituntut untuk memenuhi strategi yang tetap didalam pencapain target utama penjualan. Perilaku pembelian seseorang dapat dikatakan sesuatu yang unik, karena prefensi dan sikap terhadap objek setiap orang berbeda.

Merek adalah nama, istilah, tanda, lambang atau desain, atau kombinasi dari semua ini yang memperlihatkan identitas produk atau jasa dari satu penjual atau sekelompok penjual dan membedakan produk itu dari produk pesaing, (Kotler dan Armstrong, 2008:275).Brand image atau citra merek adalah pengaruh diferensial positif bahwa jika pelanggan mengenal nama merek, pelanggan akan merespon produk atau jasa, (Kotler dan Amstrong, 2008: 275). Harga adalah salah satu elemen bauran pemasaran yang menghasilkan pendapatan, elemen lain menghasilkan biaya, (Kotler dan Keller, 2009: 67). Keputusan pembelian adalah konsumen membentuk niat untuk membeli merek yang paling disukai, (Kotler dan Keller, 2009: 240).

Perkembangan produk deterjen yang semakin meningkat menyebabkan banyaknya pilihan deterjen yang bisa debeli oleh konsumen. Dalam menghadapi tingkat persaingan yang semakin kuat, mengharuskan sebuah perusahaan harus lebih meperhatikan kondisi pangsa pasar. Agar dapat menghadapi persaingan yang semakin ketat ini, maka perusahaan tersebut harus berupaya mengahasilkan dan menyiapkan produk yang diinginkan oleh konsumen dengan kualitas yang baik. Dengan demikian perusahaan harus mampu memahami prilaku 
kosumen khususnya pada ibu-ibu rumah tangga, karena kalansungan hidup perusahaan tersebut pada organisasi yang berusaha memenuhi kebutuhan dan keinginan para konsumen yang sangat bergantung pada perilaku konsumenya.

Rinso adalah nama merek sabun cuci atau deterjen dari unilever yang digunakan di Australia, Indonesia, Selendia Baru, Inggris dan Amerika serikat. Deterjen merek Rinso ini sudah menyebar diseluruh Indonesia diantaranya Kabupaten Musi Banyuasin Sumatera Selatan. Kabupaten Musi Banyuasin yang terdiri dari Kecematan adalah Kecematan Sungai Keruh yang terdiri dari beberapa Desa salah satunya Desa Pagar Kaya.

Tabel 1. Data Penjualan Deterjen

\begin{tabular}{|l|l|l|l|l|}
\hline No & Tahun & Rinso & Daia & Jaz 1 \\
\hline 1 & 2018 & 15.000 & 10.000 & 9.000 \\
\hline 2 & 2019 & 13.000 & 9.000 & 7.000 \\
\hline 3 & 2020 & 17.000 & 11.000 & 8.000 \\
\hline Total & & 45.000 & 30,000 & 24.000 \\
\hline
\end{tabular}

Berdasarkan tabel 1 diatas menunjukan bahwa produk deterjen merek Rinso yang paling banyak digunakan oleh masyarakat Desa Pagar Kaya Kecematan Sungai Keruh. Dengan beberapa keunggulan yang dimilikinya, walaupun jenis deterjen saat ini beraneka ragam tapi harga yang ditawarkan oleh deterjen Rinso memang sesuai dengan pendapatan dan tingkat perekonomian masyarakat golongan menengah kebawah.

\section{Tinjauan Pustaka}

\section{Brand Image (Citra Merek)}

Merek adalah suatu nama, istilah, tanda, simbol, desain atau kombinasi daripadanya untuk menandai produk atau jasa dari satu penjual atau kelompok penjual dan untuk membedakannya dari pesaing, (Hartimbul, 2011:99). Sedangkan Brand image atau citra merek adalah pengaruh diferensial positif bahwa jika pelanggan mengenal nama merek, pelanggan akan merespon produk atau jasa, (Kotler dan Amstrong, 2008: 275).

Tjiptono dan Diana (2012:17), menyatakan bahwa merek memiliki berbagai macam tujuan, yaitu:

1. Sebagai identitas perusahaan yang membedakannya dengan produk pesaing, sehingga mudah mengenali dan melakukan pembelian ulang.

2. Sebagai alat promosi yang menonjolkan daya tarik produk (misalnya dengan bentuk desain dan warna-warna menarik).

3. Untuk membina citra, yaitu dengan memberikan keyakinan, jaminan kualitas, serta citra prestise tertentu kepada konsumen.

4. Untuk mengendalikan dan mendominasi pasar. Artinya, dengan membangun merek yang terkenal, bercitra baik, dan dilindungi hak eksklusif berdasarkan hak cipta/paten, maka perusahaan dapat meraih dan mempertahankan loyalitas konsumen.

Menurut Tjiptono (2011:43) merek juga memiliki manfaat yaitu bermanfaat bagi produsen dan konsumen. Bagi produsen, merek berperan penting sebagai:

1. Sarana identifikasi untuk memudahkan proses penanganan atau pelacakan produk bagi perusahaan, terutama dalam pengorganisasian sediaan dan pencatatan akuntansi.

2. Bentuk proteksi hukum terhadap fitur atau aspek produk yang unik. Merek bisa mendapatkan perlindungan properti intelektual. Nama merek bisa diproteksi melalui 
merek dagang terdaftar (registered trademarks) proses pemanufakturan bisa dilindungi melalui hak paten dan kemasan bisa diproteksi melalui hak cipta (copyright) dan desain.

3. Signal tingkat kualitas bagi para pelanggan yang puas, sehingga mereka bisa dengan mudah memilih dan membelinya lagi dilain waktu.

4. Sarana untuk menciptakan asosiasi dan makna unik yang membedakan produk dari para pesaing.

5. Sumber keunggulan kompetitif, terutama melalui perlindungan hukum, loyalitas pelanggan, dan citra unik yang terbentuk dalam benak konsumen.

6. Sumber financial returns, terutama menyangkut pendapatan masa datang.

Menurut David (2010: 61), bahwa indikator citra merek tediri dari tiga komponen:

1. Citra pembuat (Corporate Image) yaitu: sekumpulan asosiasi yang dipersiapkan oleh konsumen terhadap perusahaan yang membuat suatu produk dan jasa.

2. Citra pakai (User Image) yaitu: sekumpulan asosiasi yang dipersiapkan oleh konsumen terhadap pemakai yang menggunakan barang atau jasa, meliputi pemakai itu sendiri, gaya hidup atau kepribadian dan status sosial.

3. Citra produk (Produk Image) yaitu: sekumpulan asosiasi yang dipersiapkan oleh konsumen terhadap suatu produk, memfaat bagi konsumen, pengunaan, serta jaminan.

\section{Harga}

Harga adalah Sejumlah uang yang dibebankan atas suatu barang atau jasa atau jumlah dari nilai uang yang ditukar konsumen atas manfaat-manfaat karena memiliki atau menggunakan produk atau jasa tersebut, (Kotler dan Armstrong, 2014:151). Harga adalah jumlah uang yang harus dibayar pelanggan untuk memperoleh produk atau jasa itu, (Kotler, 2012:132).

Tujuan penetapan harga pada setiap perusahaan berdeda-beda, sesuai dengan kepentingan. Menurut Kotler dan Keller (2012:76), pada dasarnya terdapat empat jenis penetapan harga, yaitu:

1. Tujuan Berorientasi pada Laba

Tujuan ini dikenal dengan istilah maksimisasi laba. Dalam era persaingan global yang kondisinya sangat kompleks dan banyak variabel yang berpengaruh terhadap daya saing setiap perusahaan, maksimisasi laba sangat sulit dicapai, karena sukar sekali untuk dapat memperkirakan secara akurat jumlah penjualan yang dapat dicapai pada tingkat harga tertentu.

2. Tujuan Berorientasi pada Volume

Selain tujuan berorentasi pada laba, ada pula perusahaan yang menetapkan harganya berdasarkan tujuan yang berorentasi pada volume tertentu atau yang biasa dikenal dengan istilah volume pricing objectives. Harga ditetapkan sedemikian rupa agar dapat mencapai target volume penjualan, nilai penjualan, atau pangsa pasar.

3. Tujuan Berorientasi pada Citra

Citra suatu perusahaan dapat dibentuk melalui strategi penetapan harga. Perusahaan dapat menetapkan harga tinggi untuk membentuk atau mempertahankan citra prestisius.

4. Tujuan Stabilisasi Harga

Dalam pasar yang konsumennya sangat sensitif terhadap harga. Bila suatu perusahaan menurunkan harganya, maka para pesaingnya harus menurunkan pula harga mereka.

5. Tujuan-tujuan Lainnya 
Harga dapat pula ditetapkan dengan tujuan mencegah masuknya pesaing, mempertahankan loyalitas pelanggan, mendukung penjualan ulang, atau menghindari campur tangan pemerintah.

Menurut Kotler dan Keller (2012: 77), yang menjelaskan metode penetapan harga sebagai berikut: Metode penetapan harga secara garis besar dapat dikelompokkan menjadi empat kategori utama, yaitu metode penetapan harga berbasis permintaan, berbasisi biaya, berbasis laba, dan berbasis persaingan.

Menurut Kotler dan Armstrong (2014:151), ada empat indikator yang harga yaitu:

1. Keterjangkauan harga.

2. Kesesuaian harga dengan kualitas produk.

3. Daya saing harga.

4. Kesesuaian harga dengan manfaat

\section{Keputusan Pembelian}

Keputusan pembelian merupakan tahap evaluasi, konsumen dari preferensi di antara merek di set pilihan dan mungkin juga dari niat untuk membeli merek yang paling disukai, (Kotler dan Keller, 2012: 240).

Kotler dan keller (2012: 361), menyatakan proses keputusan pembelian terdiri dari lima tahap:

1. Pengenalan Kebutuhan (Need Recognition)

Proses pembelian dimulai ketika pembeli mengenali masalah atau kebutuhan.

2. Pencarian Informasi

Seorang konsumen yang terangsang akan terdorong untuk mencari informasi yang lebih banyak. Dalam hal ini dapat dibagi kedalam dua level rangsangan. Situ asi pencarian informasi yang lebih ringan dinamakan penguatan perhatian.

3. Evaluasi Alternatif

Terdapat beberapa proses evaluasi keputusan, dan model-model terbaru yang memandang proses evaluasi konsumen sebagai proses yang berorientasi kognitif.

4. Keputusan Pembelian

Dalam tahap evaluasi, konsumen membentuk preferensi merek produk yang ada dalam kumpulan pilihan mereka. Konsumen juga dapat membentuk niat untuk membeli merek yang paling disukai.

5. Perilaku Pasca Pembelian

Tugas pemasar tidak berakhir saat produk dibeli oleh konsumen, melainkan berlanjut hingga periode pasca pembelian. Setelah pembelian produk terjadi, konsumen akan mengalami suatu tingkat kepuasan atau ketidakpuasan. Kepuasan atau ketidakpuasan konsumen terhadap produk akan mempengaruhi tingkah laku konsumen berikutnya. Konsumen yang merasa puas akan memperlihatkan peluang membeli dalam kesempatan berikutnya dan akan cenderung mengatakan sesuatu yang serba baik.

Menurut Kotler dan Keller (2012: 262), ada beberapa faktor yang dapat mempengaruh konsumen di dalam memutuskan untuk melakukan pembelian produk, faktor tersebut adalah:

1. Faktor Budaya

a. Budaya. Budaya (culture) adalah kumpulan nilai dasar, persepsi, keinginan, dan perilaku yang dipelajari oleh anggota masyarakat dari keluarga dan institusi penting lainnya. 
b. Subbudaya. Subbudaya (subculture) adalah kelompok masyarakat yang berbagi sistem nilai berdasarkan pengalaman hidup dan situasi yang umum.

c. Kelas sosial. Kelas sosial (social class) adalah pembagian yang relative dan berjenjang dalam masyarakat dimana anggotanya berbagi nilai, minat, dan perilaku yang sama.

2. Faktor Sosial

a. Kelompok (group) adalah dua atau lebih orang yang berintraksi untuk mencapai tujuan pribadi atau tujuan bersama.

b. Keluarga adalah organisasi pembelian konsumen yang paling penting dalam masyarakat, seperti suami, istri dan anak-anak.

c. Peran dan status adalah peran terdiri dari aktivitas yang diharapkan dilakukan seseorang yang ada di sekitarnya. Setiap peranmembawa status yang mencerminkan penghargaan yang diberikan oleh masyarakat.

3. Faktor Pribadi

a. Usia dan tahap siklus hidup. Membeli juga dibentuk oleh siklus hidup keluarga mengenai tahap-tahap yang mungkin dilalui keluarga sesuai kedewasaanya. Dari usia muda, usia pertengahan dan usia tua.

b. Pekerjaan. Maksudnya adalah pekerjaan seseorang mempengaruhi barang dan jasa yang mereka beli.

c. Situasi ekonomi. Situasi ekonomi mempengaruhi pilihan produk. Pemasaran produk yang peka terthadap pendapatan mengamati kecenderungan dalam pendapatan pribadi, tabungan, dan tingkat minat.

d. Gaya hidup. Gaya hidup (lifestyle) merupakan pola kehidupan seseorang yang diwujudkan dalam psikografisnya. Gaya hidup yang dimaksud adalah mengenai aktivitas (pekerjaan, hobi, berbelanja, olahraga dan kegiatan sosial), minat (makanan, mode, keluarga, rekreasi), opini (isu sosial, bisnis, produk).

e. Kepribadian dan konsep diri. Kepribadian (personality) mengacu pada karakteristik psikologi unik seseorang yang menyebabkan respons yang relatif konsisten dan bertahan lama terhadap lingkungan orang itu sendiri.

4. Faktor Psikologis

a. Motivasi. Motivasi adalah kebutuhan dengan tekanan kuat yang mendorong seseorang untuk mencari kepuasan atas kebutuhan tersebut.

b. Persepsi. Persepsi adalah proses dimana orang memilih, mengatur, dan menginterpretasikan informasi untuk membentuk gambaran dunia yang berarti.

c. Pembelajaran. Maksudnya adalah perubahan dalam perilaku seseorang yang timbul dari pengalaman.

d. Keyakinan dan sikap. Keyakinan (belief) adalah pemikiran deskriptif yang dimiliki seseorang mengenai sesuatu. Sikap (attitude) adalah evaluasi, perasaan, dan

e. Tendensi yang relatif konsisten dari seseorang terhadap suatu objek atau ide.

Menurut Kotler dan keller (2012: 36), indikator dari proses keputusan pembelian yaitu:

1. Tujuan dalam membeli produk.

2. Pemrosesan informasi untuk sampai ke pemilihan merek.

3. Kemantapan pada sebuah produk.

4. Memberikan rekomendasi kepada orang lain.

5. Melakukan pembelian. 


\section{Metodologi Peneltian}

Pelaksanaan kegiatan ini di Desa Pagar Kaya Kecamatan Sungai Keruh.

1. Data

\section{a. Data primer (primary data)}

Merupakan data yang di olah sendiri oleh suatu organisasi atau perorangan langsung dari objek penelitian. Data primer berupa penyebaran kuesioner.

b. Data sekunder (secondary data)

Merupakan data yang diperoleh dalam bentuk yang sudah jadi, dikumpulkan dan diolah pihak lain. Biasanya sudah dalam bentuk publikasi. Data sekunder berupa artikel-artikel dan literatur lainnya.

2. Operasional Variabel

Brand image atau citra merek adalah pengaruh diferensial positif bahwa jika pelanggan mengenal nama merek, pelanggan akan merespon produk atau jasa, (Kotler dan Amstrong, 2008: 275). Variabel Independen $\left(\mathrm{X}_{1}\right)$ adalah brand image. Variabel brand image diukur dengan menggunakan indikator citra pembuat, citra pemakai, dan citra produk. Harga adalah salah satu elemen bauran pemasaran yang menghasilkan pendapatan, elemen lain menghasilkan biaya, (Kotler dan Keller, 2009: 67). Variabel independen $\left(\mathrm{X}_{2}\right)$ adalah harga. Variabel harga ini diukur dengan menggunakan indikator keterjangkauang harga, kesesuaian harga dengan produk, daya saing harga dan kesesuaian harga dengan manfaat. Sedangkan Keputusan pembelian adalah konsumen membentuk niat untuk membeli merek yang paling disukai, (Kotler dan Keller, 2009: 240). Variabel dependen (Y) adalah Keputusan Pembelian. Variabel keputusan pembelian ini dapat diukur dengan menggunakan indikator tujuan membeli produk, pemprosesan informasi sampai pemilihan produk, kemantapan pada sebuah produk, memberikan rekomendasi kepada orang lain dan melakukan pembelian.

\section{Teknik Analisis Data}

a. Pengujian Validitas Data

Validitas merupakan derajat ketepatan antara data yang terjadi pada obyek penelitian dengan data yang dilaporkan oleh peneliti, (Sugiyono, 2010: 363). Syarat minimum untuk dianggap valid adalah nilai $\mathrm{r}$ hitung $>$ dari nilai $\mathrm{r}$ tabel.

b. Pengujian Reliabilitas Data

Uji reliabilitas dimaksudkan untuk mengetahui adanya konsistensi alat ukur dalam penggunaannya, atau dengan kata lain alat ukur tersebut mempunyai hasil yang konsisten apabila digunakan berkali-kali pada waktu yang berbeda, (Arikunto, 2013: 245). Untuk uji reabilitas digunakan teknik alpa cronbach, dimana suatu instrumen dapat dikatakan handal (reliable) bila memiliki koefisien keandalan atau alpha sebesar 0,6 atau lebih.

4. Uji Asumsi Klasik

1) Pengujian Normalitas

Pengujian normalitas untuk pengujian validitas tiap butir digunakan analisis item, yaitu dengan cara mengkolerasikan skor tiap butir dengan skor total yang merupakan jumlah tiap skor butir. Dalam hal analisis item, teknik kolerasi menentukan validitas item ini yang paling banyak digunakan, (Ghozali, 2011: 160-165). Dasar pengambilan untuk uji normalitas data adalah:

a. Jika data menyebar di sekitar garis diagonal dan mengikuti arah garis diagonal, maka regresi memenuhi asumsi normalitas. 
b. Jika data menyebar dari garis diagonal dan atau tidak mengikuti arah garis diagonal, maka model regresi tidak memenuhi asumsi normalitas.

2) Pengujian Multikolinearitas

Uji Multikolinearitas bertujuan untuk menguji apakah model regresi ditemukan adanya korelasi antar variabel independen. Uji multikolonieritas dilihat dari nilai tolerance dan Variance Inflantion Factor (VIF). Regresi yang baik memiliki VIF di sekitar angka 1 (satu) dan mempunyai angka Tolerance mendekati 1, (Ghozali (2011: 95)).

3) Pengujian Heteroskedastisitas

Uji ini bertujuan untuk menguji apakah dalam sebuah model regresi terjadi ketidaknyamanan varian dari residual satu pengamatan ke pengamatan lain. Jika varian berbeda, disebut heteroskedastisitas. Uji heteroskedastisitas dapat dilihat dengan menggunakan grafik plot antara nilai prediksi variabel terikat (ZPRED) dengan residual (SRESID). Jika grafik plot menunjukkan suatu pola titik seperti titik yang bergelombang atau melebar kemudian menyempit, maka dapat disimpulkan bahwa telah terjadi heteroskedastisitas. Tetapi jika grafik plot tidak membentuk pola yang jelas, maka tidak terjadi heteroskedastisitas, (Ghozali, 2011: 125-126).

5. Analisis Regresi Berganda

Untuk mengetahui pengaruh variabel bebas terhadap variabel terikatnya digunakan rumus analisis regresi linier berganda sebagai berikut:

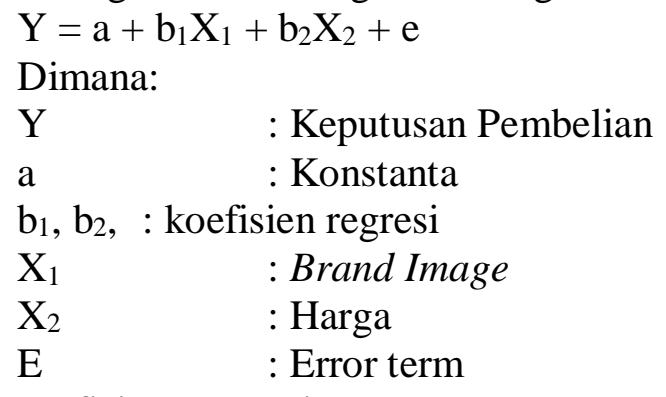

6. Uji Koefisien Determinan

Koefisien determinasi $\left(\mathrm{R}^{2}\right)$ pada intinya mengukur seberapa jauh kemampuan model dalam menerangkan variasi variabel dependen. Nilai koefisien determinasi adalah antara nol sampai satu $\left(0<\mathrm{R}^{2}<1\right)$. Nilai $\mathrm{R}^{2}$ yang kecil berarti kemampuan variable- variabel independen dalam menjelaskan variasi variabel dependen sangat terbatas. Nilai yang mendekati satu berarti variabel-variabel independen memberikan hampir semua informasi yang dibutuhkan untuk memprediksi variasi variabel dependen.

7. Uji Hipotesis

a) Uji Simultan (Uji F)

Menurut Sugiyono (2010: 257), uji F adalah pengujian terhadap koefisien regresi secara simultan. Pengujian ini dilakukan untuk mengetahui pengaruh semua variabel independen yang terdapat di dalam model secara bersama-sama (simultan) terhadap variabel dependen. Uji F dalam penelitian ini digunakan untuk menguji signifikasi pengaruh brand image dan harga secara bersama-sama terhadap variabel terikatnya, yaitu keputusan pembelian. F hasil perhitungan ini dibandingkan dengan Ftabel yang diperoleh dengan menggunakan tingkat resiko atau signifikan level 5\% atau dengan degree freedom $=\mathrm{k}(\mathrm{n}-\mathrm{k}-1)$ dengan kriterian sebagai berikut:

a. H0 ditolak jika $\mathrm{F}$ hitung $>\mathrm{F}$ tabel atau nilai sig $\propto<\operatorname{sig} \mathrm{F}$

b. H0 diterima jika F hitung $\langle F$ tabel atau nilai sig $\propto>\operatorname{sig} F$ 
b) Uji Parsial (Uji t)

Uji t (t-test) melakukan pengujian terhadap koefisien regresi secara parsial, pengujian ini dilakukan untuk mengetahui signifikansi peran secara parsial antara variabel independen terhadap variabel dependen dengan mengasumsikan bahwa variabel independen lain dianggap konstan (Sugiyono (2010: 250). (t-test) hasil perhitungan ini selanjutnya dibandingkan dengan t tabel dengan menggunakan tingkat kesalahan 0,05 . Kriteria yang digunakan adalah sebagai berikut:

a. H0 diterima jika nilai thitung $\geq \mathrm{t}$ tabel atau nilai sig $\propto<\operatorname{sig} \mathrm{t}$

b. H0 ditolak jika nilai $\mathrm{t}$ hitung $\leq \mathrm{t}$ tabel atau nilai sig $\propto \geq \operatorname{sig} \mathrm{t}$

\section{Hasil dan Pembahasan}

Desa Sungai Keruh pernah dijadikan sebagai Ibu Kota Marga Petajin Ulu, dari dahulu dikenal dengan tipe Desa Pertanian Sawah (DPS) karena pada tahun 1989 sebagian besar penduduknya bermata pencaharian pokok disektor pertanian sawah atau 36,87 persen dari jumlah penduduknya. Berikut diuraikan hasil dan pembahasannya:

1. Uji Validitas

Hasil uji validitas kuesioner dapaat dilihat pada tabel berikut:

Tabel 2. Hasil Uji Validitas Kuesioner Brand Image

\begin{tabular}{|c|l|l|l|}
\hline Pernyataan & $\mathbf{r}_{\text {hitung }}$ & $\mathbf{r}_{\text {tabel }}$ & Ket \\
\hline 1 & 0,681 & 0,361 & Valid \\
\hline 2 & 0,606 & 0,361 & Valid \\
\hline 3 & 0,654 & 0,361 & Valid \\
\hline 4 & 0,490 & 0,361 & Valid \\
\hline 5 & 0,487 & 0,361 & Valid \\
\hline 6 & 0,655 & 0,361 & Valid \\
\hline
\end{tabular}

Berdasarkan tabel diatas dapat dilihat nilai $\mathbf{r}_{\text {hitung }}>\mathbf{r}_{\text {tabel }}$ dan pada taraf signifikasi 0,05 dari $\mathrm{n}=30$ yaitu 0,361 , maka dinyatakan uji validitas Brand Image menunjukkan bahwa seluruh pertanyaan semua valid.

Tabel 3. Hasil Uji Validitas Kuesioner Harga

\begin{tabular}{|c|l|l|l|}
\hline Pernyataan & $\mathbf{r}_{\text {hitung }}$ & $\mathbf{r}_{\text {tabel }}$ & Ket \\
\hline 1 & 0,588 & 0,361 & Valid \\
\hline 2 & 0,636 & 0,361 & Valid \\
\hline 3 & 0,446 & 0,361 & Valid \\
\hline 4 & 0,422 & 0,361 & Valid \\
\hline 5 & 0,536 & 0,361 & Valid \\
\hline 6 & 0,436 & 0,361 & Valid \\
\hline 7 & 0,474 & 0,361 & Valid \\
\hline 8 & 0,422 & 0,361 & Valid \\
\hline
\end{tabular}

Berdasarkan tabel diatas dapat dilihat nilai $\mathbf{r}_{\text {hitung }}>\mathbf{r}_{\text {tabel }}$ dan pada taraf signifikasi 0,05 dari $n=30$ yaitu 0,361 . maka dinyatakan uji validitas harga menunjukkan bahwa seluruh pertanyaan semua valid.

Tabel 4. Hasil Uji Validitas Kuesioner Keputusan Pembelian 


\begin{tabular}{|l|l|l|l|}
\hline Pernyataan & $\mathbf{r}_{\text {hitung }}$ & $\mathbf{r}_{\text {tabel }}$ & Ket \\
\hline 1 & 0,634 & 0,361 & Valid \\
\hline 2 & 0,783 & 0,361 & Valid \\
\hline 3 & 0,474 & 0,361 & Valid \\
\hline 4 & 0,599 & 0,361 & Valid \\
\hline 5 & 0,429 & 0,361 & Valid \\
\hline 6 & 0,636 & 0,361 & Valid \\
\hline 7 & 0,783 & 0,361 & Valid \\
\hline 8 & 0,632 & 0,361 & Valid \\
\hline
\end{tabular}

Berdasarkan tabel diatas dapat dilihat nilai $\mathbf{r}_{\text {hitung }}>\mathbf{r}_{\text {tabel }}$ dan pada taraf signifikasi 0,05 dari $\mathrm{n}=110$ yaitu 1,874, maka dinyatakan uji validitas keputusan konsumen menunjukkan bahwa seluruh pertanyaan semua valid.

2. Uji Reliabilitas

Hasil uji reliabilitas pada setiap variabel memperoleh hasil sebagai berikut:

Tabel 5. Hasil Uji Reliabilitas Kuesioner

\begin{tabular}{|l|l|l|l|}
\hline \multicolumn{1}{|c|}{ Pernyataan } & \multicolumn{1}{|c|}{$\begin{array}{c}\text { Cron } \\
\text { Alpha }\end{array}$} & Nilai Critical & \multicolumn{1}{|c|}{ Ket } \\
\hline Brand Image & 0,642 & $\begin{array}{l}\text { Cronbach } \\
\text { alpha > 0,60 } \\
\text { maka reliabel }\end{array}$ & Reliabel \\
$\begin{array}{l}\text { Keputusan } \\
\text { Pembelian }\end{array}$ & 0,666 & Reliabel \\
\hline
\end{tabular}

Hasil uji reliabilitas sebesar 0,642 untuk Brand Image, untuk Harga 0,777 dan untuk faktor keputusan pembelian 0,666 , nilai tersebut menunjukkan bahwa semua varibel mempunyai koefisien Cronbach alpha yang cukup besar yaitu diatas 0,60 sehingga dapat dikatakan semua konsep pengukuran masing-masing variabel dari kuesioner adalah reliabel sehingga untuk selanjutnya item-item pada masing-masing konsep variabel tersebut layak digunakan sebagai alat ukur. Artinya semua variabel berjalan konsisten dan tidak berubah-ubah.

3. Hasil Uji Asumsi Klasik

a.Uji Normalitas

Normal P-P Plot of Regression Standardized Residual

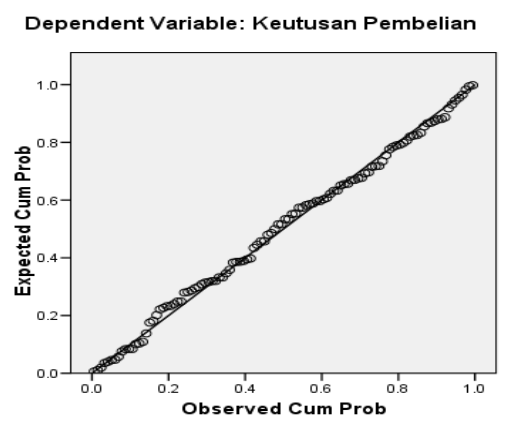

Histogram

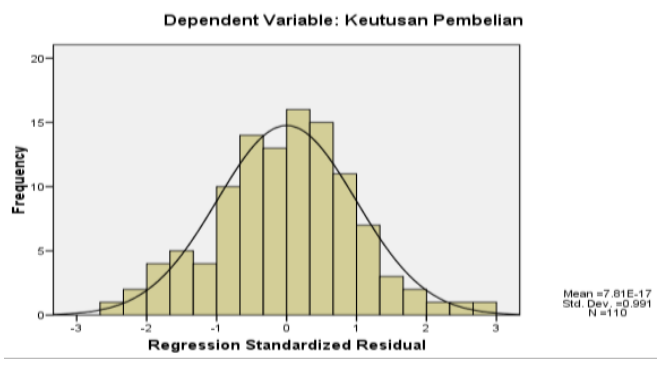


Gambar 1. Hasil Uji Normalitas

Berdasarkan gambar diatas, dapat dilihat bahwa data menyebar disekitar garis diagonal dan mengikuti arah garis diagonal atau grafik histogramnya menunjukkan pola distribusi normal.

b.Uji Multikolinearitas

Tabel 6. Hasil Uji Multikolinearitas

\begin{tabular}{|c|c|c|c|c|c|c|c|c|}
\hline \multicolumn{9}{|c|}{ Coefficients } \\
\hline & & \multicolumn{2}{|c|}{$\begin{array}{c}\text { Unstandardized } \\
\text { Coefficients }\end{array}$} & \multirow{2}{*}{$\begin{array}{l}\text { Standardized } \\
\text { Coefficients } \\
\text { Beta }\end{array}$} & \multirow[b]{2}{*}{ t } & \multirow[b]{2}{*}{ Sig. } & \multicolumn{2}{|c|}{ Collinearity Statistics } \\
\hline \multicolumn{2}{|c|}{ Model } & B & Std. Error & & & & Tolerance & VIF \\
\hline \multirow[t]{3}{*}{1} & (Constant) & 7,909 & 1,916 & & 4,128 &, 000 & & \\
\hline & Brand Image &, 767 & ,078 & .635 & 9,806 & .000 & .995 & 1,005 \\
\hline & Harga & 186 & ,028 & 434 & 6,698 & , 000 & ,995 & 1,005 \\
\hline
\end{tabular}

Pada tabel coefficient di atas, bahwa nilai rentangnya sempit, yaitu pada $\mathrm{X}_{1}=0,995$ sampai dengan 1,005 . Sedangkan pada $\mathrm{X} 2$ juga kebetulan hasilnya sama yaitu $\mathrm{X}_{2}=$ 0,995 sampai dengan 1,005 . Karena rentangnya sempit maka multikolinearitas tidak terdeteksi.

c. Uji Hesteroskedastisitas

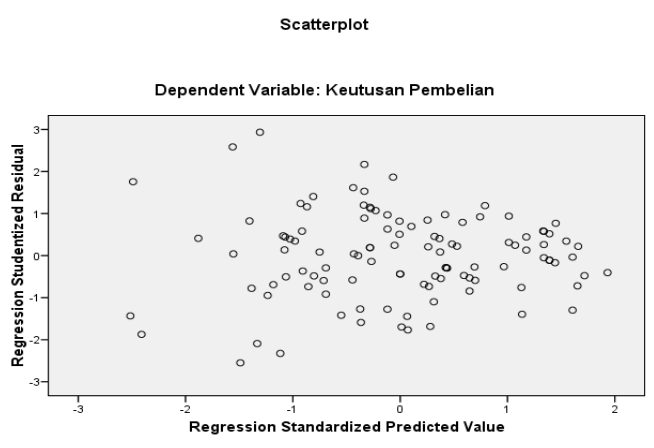

Gambar 2. Hasil Uji Hesteroskesdastisitas

Dari gambar diatas terlihat titik-titik menyebar secara acak serta tersebar baik diatas atau dibawah angka 0 pada sumbu Y. Hal ini menunjukkan tidak terjadi heteroskedastisitas pada model regresi (lampiran) sehingga model regresi layak dipakai untuk memprediksi keputusan pembelian berdasarkan masukan variabel independennya yaitu brand image dan harga.

4. Hasil Analisis Regresi Linear Berganda

Tabel 7. Hasil Regresi Linear Berganda

\begin{tabular}{|c|c|c|c|c|c|c|}
\hline \multicolumn{7}{|c|}{ Coefficients } \\
\hline & & \multicolumn{2}{|c|}{$\begin{array}{l}\text { Unstandardized } \\
\text { Coefficients }\end{array}$} & $\begin{array}{l}\text { Standardized } \\
\text { Coefficients }\end{array}$ & & \\
\hline \multicolumn{2}{|c|}{ Model } & B & Std. Error & Beta & $t$ & Sig. \\
\hline \multirow[t]{3}{*}{1} & (Constant) & 7,909 & 1,916 & & 4,128 &, 000 \\
\hline & Brand Image & ,767 & ,078 &, 635 & 9,806 & ,000 \\
\hline & Harga & , 186 & .028 & .434 & 6,698 & .000 \\
\hline
\end{tabular}

a. Dependent Variable: Keutusan Pembelian 
Berdasarkan table diatas dapat diketahui persamaan regresi yang terbentuk adalah:

$Y=7.909+0.767 X 1+0.186 X 2$

Persamaan regresi diatas dapat dijelaskan sebagai berikut:

a: 7,909 menunjukkan jika $\mathrm{x}$ atau brand image dann harga konstan, maka keputusan pembelian sebesar 7,909.

b1: 0,767 menunjukkan bahwa setiap perubahan satuan skor brand image, akan menambah keputusan pembelian sebesar 0,767 .

b2: 0,186 menunjukkan bahwa setiap perubahan satuan skor harga, akan menambah keputusan pembelian sebesar 0,186 .

5. Uji Determinasi

Tabel 8. Hasil Uji Determinasi $\left(\mathrm{R}^{2}\right)$

Model Summary

\begin{tabular}{|l|r|r|r|r|}
\hline Model & \multicolumn{1}{|c|}{$\mathrm{R}$} & R Square & $\begin{array}{r}\text { Adjusted } \\
\text { R Square }\end{array}$ & $\begin{array}{r}\text { Std. Error of } \\
\text { the Estimate }\end{array}$ \\
\hline 1 &, $744^{\mathrm{a}}$ &, 553 &, 545 & 3,22502 \\
\hline
\end{tabular}

a. Predictors: (Constant), Harga, Brand Image

Berdasarkan tabel diatas diperoleh angka $\mathrm{R} 2$ ( $\mathrm{R}$ Square) sebesar 0,553. Hal ini menunjukkan bahwa persentase sumbangan pengaruh brand image dan harga berpengaruh sebanyak 55,3\%, sedangkan sisanya sebesar 44,7\% dijelaskan atau dipengaruhi oleh variabel lain yang tidak diteliti, misalnya atribut produk, iklan dan lain-lain.

8. Uji Hipotesis

a) Uji t (Parsial)

Tabel 9. Hasil Uji t

\begin{tabular}{|c|c|c|c|c|c|c|}
\hline \multicolumn{7}{|c|}{ Coefficients } \\
\hline & & \multicolumn{2}{|c|}{$\begin{array}{l}\text { Unstandardized } \\
\text { Coefficients }\end{array}$} & \multirow{2}{*}{$\begin{array}{c}\text { Standardized } \\
\text { Coefficients }\end{array}$} & \multirow[b]{2}{*}{$t$} & \multirow[b]{2}{*}{ Sig. } \\
\hline \multicolumn{2}{|c|}{ Model } & B & Std. Error & & & \\
\hline \multirow[t]{3}{*}{1} & (Constant) & 7,909 & 1,916 & & 4,128 &, 000 \\
\hline & Brand Image & ,767 & 078 & ,635 & 9,806 &, 000 \\
\hline & Harga & 186 & ,028 & ,434 & 6,698 &, 000 \\
\hline
\end{tabular}

Berdasarkan tabel diatas dapat dilihat bahwa sig brand image dan harga 0.000 lebih kecil dari sig a, hal ini berarti brand image dan harga secara parsial berpengaruh terhadap keputusan pembelian deterjen merek Rinso di Desa Pagar Kaya Kecamatan Sungai Keruh.

b) Uji F

Tabel 10. Hasil uji F

\begin{tabular}{|c|c|c|c|c|c|c|c|c|}
\hline & \multicolumn{6}{|c|}{ ANOVAP } & & \\
\hline & Model & \multirow{2}{*}{$\begin{array}{l}\text { Sum of } \\
\text { Squares } \\
1379,520\end{array}$} & $d f$ & Mean Square & \multirow{2}{*}{$\frac{F}{66,318}$} & \multirow{2}{*}{ Sig. } & & \\
\hline & \begin{tabular}{|ll}
1 & Regression
\end{tabular} & & 2 & 689,760 & & & \multirow{3}{*}{ EN KOMPETEN } & \\
\hline JULI 202 & $\begin{array}{l}\text { Residual } \\
\text { Total }\end{array}$ & $\begin{array}{l}1112,880 \\
2492,400\end{array}$ & $\begin{array}{l}107 \\
109\end{array}$ & 10,401 & & & & \multirow[t]{2}{*}{ Page 24} \\
\hline & a. Predictors: (Con & nt), Harga & d lmag & & & & & \\
\hline
\end{tabular}


Berdasarkan tabel diatas, dapat dilihat bahwa sig F sebesar 0.000, ini lebih kecil dari sig a. Hal ini berarti brand image (X1) dan harga (X2) secara bersama-sama atau serempak berpengaruh secara signifikan terhadap keoputusan pembelian deterjen Merek Riinso di Desa Pagar Kaya Kecamatan Sungai Keruh.

\section{Simpulan}

Adapun simpulannya antara lain sebagai berikut:

1. Hasil Uji Normalitas data menampilkan grafik normal. Plot yang ada menunjukkan titik menyebar disekitar garis diagonal, serta penyebaran mengikuti arah garis diagonal, demikian juga dengan grafik histogram memberikan pola distribusi normal. Maka model regresi layak dipakai untuk memprediksi keputusan pembelian berdasarkan masukan variabel independennya yaitu brand image dan harga.

2. Hasil Uji Miltikolinearitas diketahui bahwa nilai rentangnya sempit, yaitu pada $\mathrm{X} 1=$ 0,995 sampai dengan 1,005 . Sedangkan pada X2 juga kebetulan hasilnya sama yaitu X2 = 0,995 sampai dengan 1,005. Karena rentangnya sempit maka multikolinearitas tidak terdeteksi.

3. Hasil Uji Heteroskedastisitas dari grafik Scatterplot penelitian ini terlihat titik-titik menyebar secara acak serta tersebar baik diatas maupun dibawah angka 0 pada sumbu Y. hal ini menunjukkan tidak terjadi Heteroskedastisitas pada model regresi (lampiran) sehingga model regresi layak dipakai untuk memprediksikan keputusan siswa berdasarkan masukan variabel independennya yaitu faktor sosial dan faktor psikologis

4. Persamaan Regresi linier berganda $\mathrm{Y}=7.909+0.767 X 1+0.186 X 2$

5. Hasil uji t menunjukan bahwa sig t yang diperoleh Brand Image dan Harga 0.000 lebih kecil dari 0.05, artinya Brand Image dan harga secara parsial berpengaruh keputusan pembelian deterjen merek rindo di Desa Pagar Kaya Kecamatan Sungai Keruh berarti hipotesis dalam penelitian ini benar.

6. hasil uji F menunjukkan bahwa sig F sebesar 0.000 lebih kecil dari 0.05, berarti Brand Image $\left(\mathrm{X}_{1}\right)$ dan harga $\left(\mathrm{X}_{2}\right)$ secara bersama-sama atau serempakberpengaruh signifikan terhadap keputusan pembelian deterjen merek rinso di Desa Pagar Kaya Kecamatan Sungai Keruh.

\section{DAFTAR PUSTAKA}

[1] Arikunto, Suharsimi, dkk. 2013. Penelitian Tindakan Kelas. Jakarta: Bumi Akrasa.

[2] David A. And Alexander L Biel. 2010. Brand Equity and Advertising: Advertising Role in Building Strong Brands. LawrenceErlbaum Associats, Inc, Hillsdale.

[3] Ghozali, Imam. 2011. Aplikasi Analisis Multivariat dengan Program IBM SPSS 21. Edisi 7. Semarang: Universitas Diponegoro

[4] Kotler, Amstrong. 2008. Prinsip-prinsip pemasaran 2. Edisi 12. Jakarta: Erlangga.

[5] Kotler, dan Keller. 2009. Manajemen Pemasaran dan pemasaran jasa. Bandung: Alfabeta

[6] Kotler, Philip. \& Gary Armstrong. 2014.Principle of Marketing, 15th edition. New Jersey: Pearson Prentice Hall. 
JURNAL MANAJEMEN KOMPETEN

Vol. 4 No.1 Juli 2021, 14-26

[7] Kotler, Philip and Kevin Lane Keller. 2012, Maraketing Manajemen 13. New Jersey: Pearson Prentice Hall, Inc.

[8] Sugiyono. 2010. Metode Penelitian Kuantitatif Kualitatif dan R\&B. Bandung: Alfabeta.

[9] Tjiptono Fandy, dan Anastasia Diana. 2012. Brand Manajemen dan Strategy. Jakarta: Penerbit Andi

[10] Tjiptono Fandy. 2011. Pemasaran Jasa. Malang: Bayumedia. 